\title{
rhGH Treatment in Corticosteroid-Treated Patients
}

\section{Dominique Simon}

Service d'Endocrinologie et de Diabétologie Pédiatrique, Hôpital Robert Debré, Assistance Publique-Hôpitaux de Paris, Paris, France

\section{Key Words}

Chronic diseases - Growth retardation • Body composition • Glucocorticoids $\cdot$ Growth hormone treatment

\begin{abstract}
Children and adolescents treated for chronic diseases have non-specific metabolic abnormalities that lead to decreased growth velocity and abnormal body composition, including severe osteoporosis, muscle wasting and increased fat mass. Glucocorticoid (GC) therapy plays a major role in the complex pathogenesis of these metabolic abnormalities. Recombinant human growth hormone ( $\mathrm{rGH}$ ) therapy was introduced a few years ago to reduce the severe disease- and GC-related metabolic consequences of juvenile idiopathic arthritis, other chronic diseases, and renal transplantation. Short-and mid-term rhGH treatment has consistently proved effective in overcoming GC-induced growth suppression, with a marked interindividual variability in the growth response to rhGH treatment. Safety of rhGH treatment, concerning the progression of the disease and glucose tolerance, was good. Prolonged follow-up until achievement of adult height is needed to better evaluate the impact of rhGH treatment on growth and body composition and the longterm consequences of hyperinsulinism.
\end{abstract}

Copyright $\odot 2007$ S. Karger AG, Basel (c) 2007 S. Karger AG, Basel

0301-0163/07/0681-0038\$23.50/0

Fax +41613061234 E-Mail karger@karger.ch www.karger.com
Accessible online at:

www.karger.com/hre

\section{Introduction}

Glucocorticoids (GC) are used in many paediatric diseases, such as inflammatory diseases and corticosteroidsensitive nephrotic syndrome, and they are also used after organ transplants. Most of these patients require longterm steroid therapy during infancy and/or puberty, which are critical developmental phases. Despite the great efficacy of these drugs, there are severe side effects, including possible long-term effects on adult height and body composition. During the past 10 years, recombinant human growth hormone (rhGH) has been used as an anabolic agent, to counteract the deleterious effects of longterm steroid therapy. Here, we discuss the different mechanisms involved in the long-term complications of steroid therapy and chronic disease. We also examine the efficacy and the safety of rhGH treatment in GC-treated children.

\section{Clinical Impact of Long-Term Glucocorticoid Treatment in Chronically-Diseased Children}

Growth retardation is a prominent feature in chronically-diseased children. Data about growth in GC-treated patients are available for children suffering from Crohn's disease (CD) $[1,2]$, juvenile idiopathic arthritis (JIA) [3-5], cortico-sensitive nephrotic syndrome [6-8]

Dr. Dominique Simon

Service d'Endocrinologe et de Diabétologie Pédiatriques

INSERM Unit 457, 48, boulevard Sérurier

FR-75019 Paris (France)

Tel. +33 14003 3634, Fax +33 14003 2429, E-Mail dominique.simon@rdb.aphp.fr 
Fig. 1. Changes in height SDS throughout follow-up in a group of 24 patients suffering from JIA. Note the marked loss of height during GC therapy and the partial catch-up growth after prednisone discontinuation.

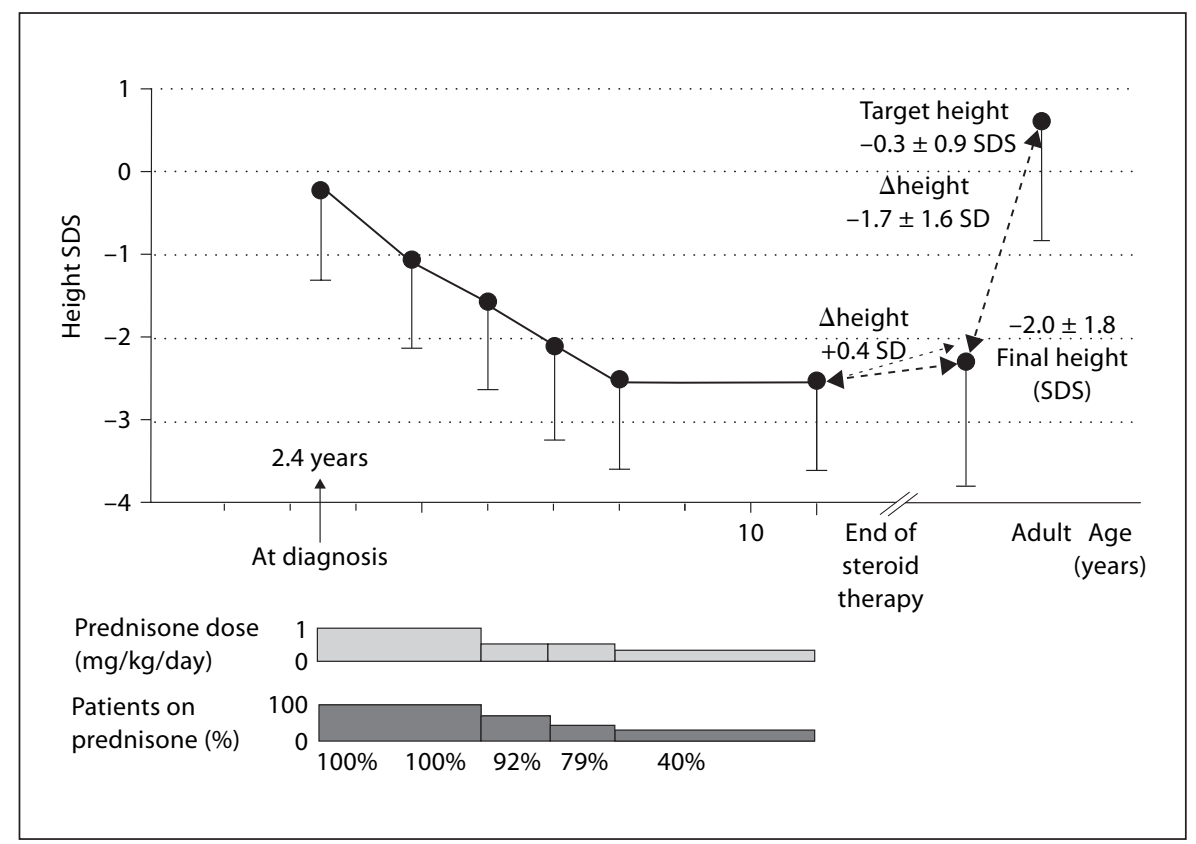

and for renal transplanted children [9-12]. In all these diseases, the severity of growth retardation mainly depends on the age at disease onset, on the severity of the disease (i.e. frequency of relapses, renal function, frequency of acute graft rejections) and consequently on the duration and dose of GC. Various additive factors contribute to growth retardation during the course of the disease, and ultimately to short adult height: (1) a marked loss of height, occurring soon after the first clinical symptoms and persisting during the active phase of the disease; (2) delayed puberty with a reduced pubertal growth spurt [13-16], and (3) variable resumption of growth after recovery from disease and the end of GC treatment. These events are illustrated in figures 1 and 2 , which show the changes in height SDS in JIA patients from diagnosis until adult height. In this study [5], a strong correlation was found between adult height and height at the end of steroid therapy (fig. 3), a result that points to the significant impact of disease and GC therapy on growth. Major changes in body composition, such as muscle wasting, fat accumulation and bone demineralisation, all of which may have important clinical consequences, have been reported in GC-treated patients. Muscle wasting may have a negative impact on the quality of life by reducing physical performances [17]. Long-term GC treatment in growing children and adolescents may also have deleterious effects on peak bone mass and thereby significantly increase the risk of fractures in adulthood $[18,19]$.

rhGH Treatment in Corticosteroid-

Horm Res 2007;68:38-45

\section{Mechanisms Leading to Growth and Metabolic Disturbances}

\section{The Effects of Glucocorticoids}

Catabolic effects of GC have been extensively investigated in clinical and experimental studies. GC are involved in growth retardation by interfering with the $\mathrm{GH} /$ IGF1 axis. Long-term corticosteroid treatment alters the pulsatility and secretion of GH by increasing the somatostatin inhibitor tone. GC also reduce the expression of $\mathrm{GH}$ receptors in hepatocytes, leading to lower IGF1 mRNA levels in the liver [20]. In clinical practice, various hormonal profiles [21] have been reported: low or normal GH levels with low IGF1 levels, or high GH levels with low IGF1 levels, reflecting a certain degree of GH resistance. However, normal GH and IGF1 levels have also been reported in GC-treated patients, suggesting that GC also exert direct effects on the growth plate. In vitro studies in different bone cell lines have shown that exposure to GC can alter precursor cell proliferation. GC decrease chondrocyte proliferation [22] and also inhibit the transcription of the GH receptor in chondrocyte cell cultures thus decreasing IGF1 production [23]. GC also decrease matrix proteoglycan synthesis. Overall, the growth retardation observed in GC patients may be due to delayed senescence of the growth plate [24] and the availability for catch-up growth will be partly mediated by changes at the growth plate level and will depend on the duration of exposure to GC [25]. 
Fig. 2. Changes in height SDS throughout follow-up in JIA patients divided into two groups according to the presence (upper line) or absence (lower line) of catch-up growth after prednisone discontinuation. Final height was significantly greater in the patients with partial catch-up growth.

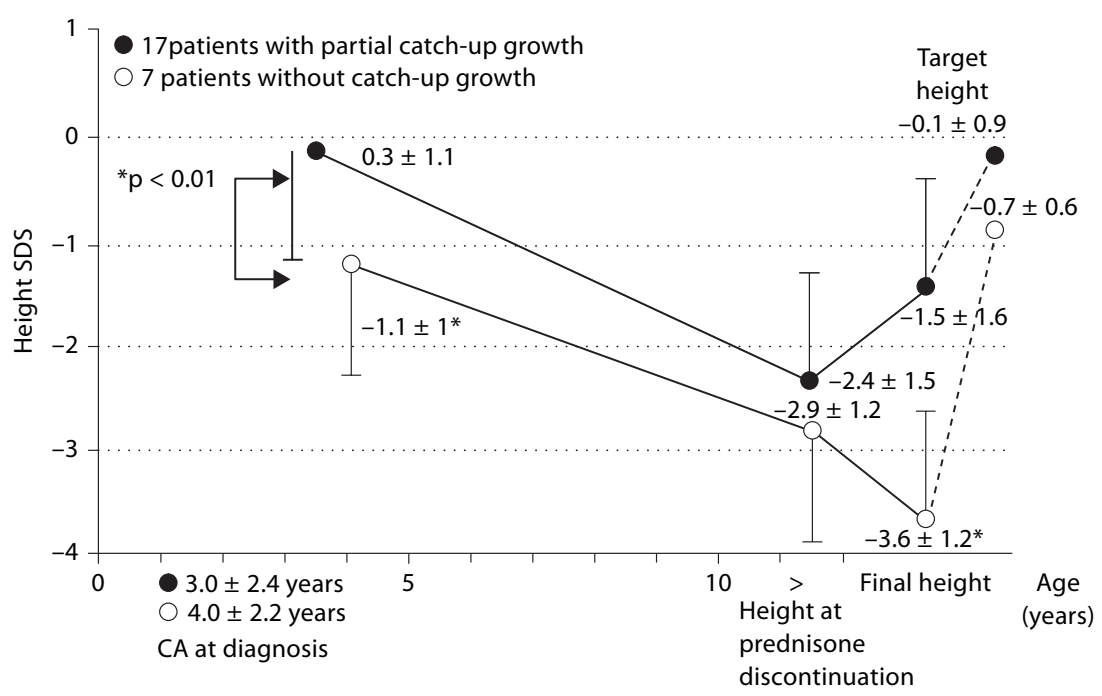

Long-term GC treatment is the main cause of osteoporosis [26], and exposure to GC induces an early bone loss that persists during GC therapy. During the first months of treatment, GC enhances bone resorption while simultaneously decreasing the new bone formation, thus leading to a net bone loss. GC enhances bone resorption by stimulating osteoclast activity. The decrease in new bone formation during GC treatment is due to a reduction in the number of osteoblasts, which in turn is due to decreased osteoblastogenesis and increased apoptosis of mature osteoblasts.

Cushingoid syndrome results from muscle wasting and fat accumulation, predominantly in the face and in the abdominal region. Different techniques have been used to study the alterations in fuel metabolism and the changes in body composition resulting from GC exposure. Studies using tracers of essential amino acids (leucine) have shown that GC increase whole body proteolysis and leucine oxidation, enhancing net protein catabolism although protein synthesis is unchanged [27]. Adipose tissue biopsies from women suffering from Cushing's syndrome revealed enlarged abdominal fat cells. These adipocytes, unlike those of normal obese women, had low lipolytic activity but had high lipoprotein-lipase (the enzyme that controls triglyceride uptake by adipocytes) activity, which may explain abdominal fat accumulation during GC exposure [28]. Indirect calorimetry [29] from organ transplant patients revealed that fasting fat oxidation decreased in a dose-dependent

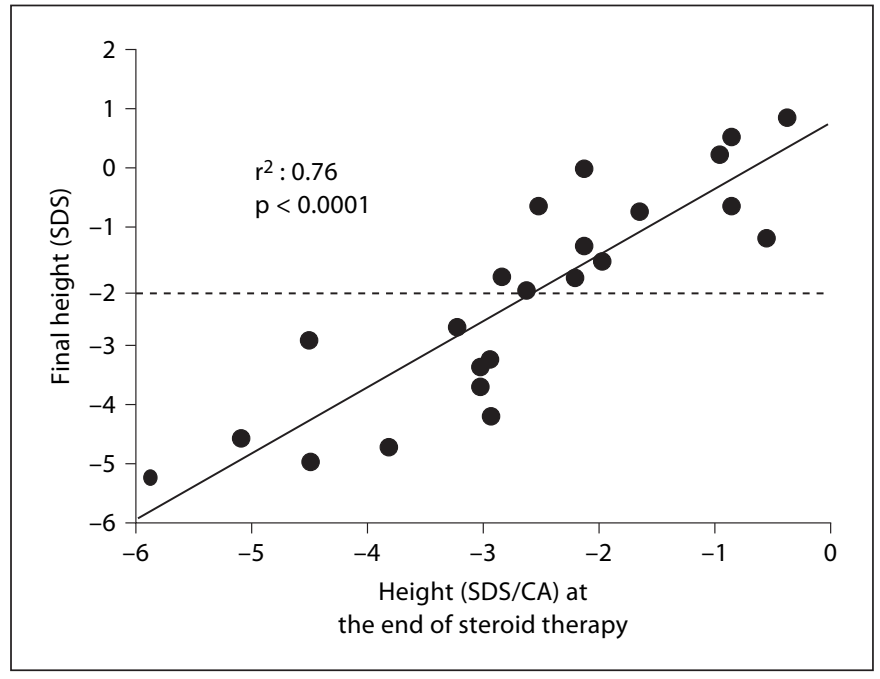

Fig. 3. Correlation between final height SDS/CA and height SDS at the discontinuation of GC. Published in Simon et al. [5].

manner in the months following a kidney graft, while proteins and carbohydrates were preferentially used to sustain fasting energy expenditure during GC exposure.

\section{The Effects of Chronic Disease}

Chronic disease often entails energy malnutrition and relative vitamin $\mathrm{D}$ deficiency due to infrequent outdoor exposure, which may contribute to growth failure, mus- 
cle wasting and poor bone mineralisation. Disease-specific factors may also be involved. The loss of growth-promoting factors (IGF1) in urine may play a role in growth retardation reported in patients suffering from nephrotic syndrome [30]. During the inflammatory process in JIA, $\mathrm{CD}$, cystic fibrosis or asthma, large amounts of cytokines (TNF $\alpha$, IL-1, and IL-6) are produced locally and in the systemic circulation. Clinical and experimental observations support the idea that these cytokines may contribute to growth failure. For example, a reduction in inflammation in CD patients by local intestinal resection or enteral nutrition is followed by a dramatic improvement in growth velocity and pubertal progression [31]. Transgenic mice that overexpress IL- 6 exhibit severe growth retardation [32]. This growth retardation can be abolished by the immuno-neutralisation of IL-6. Cytokines that enhance proteolysis and osteoclast activity might also be involved in the pathogenesis of osteoporosis and muscle wasting in chronically-diseased patients. These observations emphasise the tight link between chronic disease and GC in the genesis of growth and metabolic disturbances in children suffering from cortico-dependent diseases.

\section{Rationale for rhGH Treatment in GC-Treated Patients}

GH has linear-growth, protein-anabolic and boneprotective effects, and significant effects on fat metabolism. GH increases nitrogen retention, protein synthesis and lean body mass. It decreases adiposity by increasing fat mobilisation and lipid oxidation. GH is important in the regulation of both bone formation and bone resorption. GH stimulates the proliferation of osteoblasts and promotes the differentiated function of these cells, including the synthesis of alkaline phosphatase, osteocalcin and type I collagen synthesis. However, GH also stimulates osteoclastic bone resorption. The effects of GH on bone are biphasic. Initially, GH increases bone resorption with a concomitant bone loss, followed by a later increase in bone formation. These anabolic effects have been widely reported during rhGH treatment in GH-deficient patients, in non-GH-deficient Turner syndrome patients, and in chronic renal failure or in growth-retarded children born small for gestational age. Treatment with rhGH has been tried in many catabolic situations such as in haemodialysis [33], in cystic fibrosis patients [34] or after surgery to improve protein metabolism and accelerate recovery [35]. GH treatment may therefore be a promising therapeutical option to counteract the catabolic effects of
GC. Experiments using radioisotope tracers have shown that GH can prevent GC-induced protein wasting by increasing protein synthesis in healthy volunteers [36] and in adult patients [37]. GH treatment can also counteract GC-induced side effects on the skeleton of growing, GCtreated rats [38].

\section{Effects of rhGH Therapy in Glucocorticoid-Treated Patients}

rhGH treatment has been used in various diseases requiring steroid therapy, in both short- and long-term clinical trials (table 1). In the 90s, European and US clinical studies showed that rhGH treatment was effective and safe in prepubertal and pubertal organ transplant children. It improved height SDS $[39,40]$ and body composition [41].

Then, GH treatment was used in children with growth failure due to JIA and CD. Different doses of rhGH were used, ranging from 0.33 to $0.46 \mathrm{mg} / \mathrm{kg} /$ week. Data from non-controlled short-term studies (1 year of rhGH treatment) were encouraging, and showed that rhGH treatment improved growth velocity and induced favourable changes in body composition such as a gain in lean mass or fat free mass, a decrease in adiposity, and an increase in bone calcium accretion and bone formation [42-44]. Long-term studies, mainly from JIA children, were consistent with the short-term data. In a 4-year controlled study, Bechtold et al. [45] reported a height gain of $1 \mathrm{SD}$ in GH-treated patients, although the control group experienced a height loss of 0.7 SD. Significant improvements in body composition, lean mass and bone mineralisation were observed in two rhGH therapy trials $[46$, 47]. This was recently confirmed in a controlled study showing that GH-treated children had higher muscle mass and BMC, assessed by PQCT (peripherical computed tomography), than control subjects [48]. Further analysis of adult height and body composition in these patients are needed to evaluate the overall beneficial effects of rhGH treatment in chronically-diseased patients.

However, there is great variability in the response to rhGH treatment among GC-treated children. In some cases, rhGH treatment can induce catch-up growth but in others, it can only restore linear growth and prevent the height loss that usually occurs during the natural course of the disease. Children who exhibit the best growth response also have the most significant changes in body composition. This variability in the response to 
Table 1. Summary of studies analysing GH therapy in various diseases requiring steroid therapy

\begin{tabular}{|c|c|c|c|c|c|c|c|c|c|c|c|c|c|c|c|}
\hline & \multirow{3}{*}{$\begin{array}{l}\text { Study } \\
\text { type }\end{array}$} & \multirow{3}{*}{$\begin{array}{l}\text { Duration } \\
\text { of GH } \\
\text { treatment } \\
\text { years }\end{array}$} & \multirow[t]{3}{*}{$\mathrm{n}$} & \multicolumn{5}{|c|}{$\mathrm{GV}, \mathrm{cm} /$ year } & \multicolumn{5}{|l|}{ Height } & \multirow{3}{*}{$\begin{array}{l}\text { Prednisone } \\
\text { dose }\end{array}$} & \multirow[t]{3}{*}{ Disease } \\
\hline & & & & \multirow{2}{*}{$\begin{array}{l}\text { baseline } \\
\mathrm{cm} / \text { year }\end{array}$} & \multicolumn{4}{|l|}{ year } & \multirow{2}{*}{$\begin{array}{l}\text { baseline } \\
\text { SDS }\end{array}$} & \multicolumn{4}{|l|}{ year } & & \\
\hline & & & & & 1 & 2 & 3 & 4 & & 1 & 2 & 3 & 4 & & \\
\hline $\begin{array}{l}\text { Van Es } \\
(1957)\end{array}$ & $\begin{array}{l}\text { obser- } \\
\text { vational }\end{array}$ & 2 & 14 & 3.5 & 8.5 & 5.5 & & & -2.5 & -1.5 & -1.5 & & & NA & $\begin{array}{l}\text { renal } \\
\text { transplant }\end{array}$ \\
\hline $\begin{array}{l}\text { Davies } \\
\text { et al. [50] }\end{array}$ & $\begin{array}{l}\text { obser- } \\
\text { vational }\end{array}$ & 1 & 18 & 2.1 & 6.0 & & & & NA & NA & & & & 5-11 mg/day & JIA \\
\hline $\begin{array}{l}\text { Touati } \\
\text { et al. [43] }\end{array}$ & $\begin{array}{l}\text { obser- } \\
\text { vational }\end{array}$ & 1 & 15 & 1.9 & 5.4 & & & & -4.3 & -4.3 & & & & $0.38 \mathrm{mg} / \mathrm{kg} /$ day & JIA \\
\hline $\begin{array}{l}\text { Allen } \\
\text { et al. [56] }\end{array}$ & $\begin{array}{l}\text { obser- } \\
\text { vational }\end{array}$ & 2 & 83 & 3.0 & 6.3 & 6.3 & & & -3.7 & -3.5 & -3.5 & & & $0.5 \mathrm{mg} / \mathrm{kg} /$ day & $\begin{array}{l}\text { PT, ID } \\
\text { asthma }\end{array}$ \\
\hline $\begin{array}{l}\text { Mauras } \\
\text { et al. [42] }\end{array}$ & $\begin{array}{l}\text { obser- } \\
\text { vational }\end{array}$ & 1 & 10 & 3.5 & $\begin{array}{l}7.4 \\
(\mathrm{n}=\end{array}$ & & & & -1.7 & -1.2 & & & & $8 \mathrm{mg} /$ day & IBD \\
\hline $\begin{array}{l}\text { Simon } \\
\text { et al. [46] }\end{array}$ & $\begin{array}{l}\text { obser- } \\
\text { vational }\end{array}$ & 3 & 13 & 2.1 & 6.0 & 5.0 & 4.1 & & -4.6 & -4.5 & -4.5 & -4.3 & -3 & $0.39 \mathrm{mg} / \mathrm{kg} /$ day & JIA \\
\hline $\begin{array}{l}\text { Bechtold } \\
\text { et al. [45] }\end{array}$ & $\begin{array}{l}\text { con- } \\
\text { trolled }\end{array}$ & 4 & $\begin{array}{l}18 \mathrm{~T} \\
20 \mathrm{C}\end{array}$ & NA & NA & & & & $\begin{array}{l}-3.3 \\
-2.3\end{array}$ & $\begin{array}{l}-2.9 \\
-2.6\end{array}$ & $\begin{array}{l}-2.8 \\
-2.8\end{array}$ & $\begin{array}{l}2.5 \\
2.9\end{array}$ & $\begin{array}{r}-2.3 \\
3.0\end{array}$ & $\begin{array}{l}0.2 \mathrm{mg} / \mathrm{kg} / \text { day } \\
0.2 \mathrm{mg} / \mathrm{kg} / \text { day }\end{array}$ & JIA \\
\hline
\end{tabular}

GH doses ranged from 0.33 to $0.46 \mathrm{mg} / \mathrm{kg} /$ week. Note the marked decrease in growth velocity $(\mathrm{GV})$ and the severity of growth retardation before GH treatment.

$\mathrm{IBD}=$ Inflammatory bowel disease; ID = inflammatory diseases; JIA = juvenile idiopathic arthritis; PT = post-transplant.

rhGH treatment is mainly due to the severity of the underlying disease. For example, in JIA patients, marked differences in growth responses have been reported according to the type of the disease (polyarticular or systemic forms of JIA) [49] and negative correlations have been found between growth velocity and either prednisone dosage $[43,45,46]$ or markers of inflammation (ESR, CRP) $[45,50]$. The duration of exposure to GC, which has deleterious effects on the growth plate and metabolism, might also influence the response to rhGH treatment. For severely growth-retarded children who have already had many years of GC exposure, severe osteoporosis and muscle wasting, subsequent rhGH treatment probably could not reverse the growth retardation and probably would not lead to the normalisation of their adult height and body composition. The prevention of severe growth and metabolic disturbances with early administration of GH therapy in GC-treated patients might be a better strategy than using rhGH to cure the problems caused by long-term GC treatment. A clinical trial is currently addressing this issue.

\section{Safety of rhGH Therapy in Glucocorticoid-Treated Patients}

Two important issues should be discussed concerning the safety of rhGH treatment in GC-treated patients: the potential impact of rhGH treatment on the course of the disease and the diabetogenic effect of high dose rhGH treatment in GC-treated children.

GH can interact with the immune system [51], and therefore the potential for GH-induced activation of the immune system in patients suffering from autoimmune diseases should be investigated. In JIA patients, no significant changes in disease activity and/or joint scores have been reported during rhGH treatment $[43,45,49]$. Flares have been reported during rhGH administration but a direct relationship between flares and rhGH treatment has not been proven. Conversely, in adult CD patients, an improvement in the disease activity score has been reported after a 4-month rhGH treatment, suggesting that $\mathrm{GH}$ may be beneficial in these patients [52]. However, this improvement in disease activity was not observed during short-term rhGH treatment in children with CD [42]. In children with kidney transplants, controlled studies [53] revealed no difference between the 
GH-treated group and the control group in the incidence of acute rejection. However, a French study [54] reported that more than one acute rejection episode prior to rhGH treatment was a risk factor for subsequent episodes during rhGH treatment. rhGH treatment in GC patients appears to be safe and does not significantly modify the course of disease. However, a careful clinical follow-up, monitored by both the paediatric endocrinologist and the physician in charge of the underlying disease, is recommended to confirm the safety of rhGH treatment in these patients.

High-dose rhGH treatment appears to counteract the catabolic effects of GC in severely ill children. However, chronic administration of rhGH induces compensatory hyperinsulinaemia and relative insulin resistance in $\mathrm{GH}$ and non-GH deficient patients. In GC-treated patients, chronic rhGH treatment should be used with caution as GH and GC have similar effects on carbohydrate metabolism, and these effects are enhanced during combined treatment [55]. In studies of rhGH treatment in GC-treated patients, glucose tolerance has been investigated by the monitoring of fasting glycaemia, insulinaemia, and glycosylated haemoglobin, or by the annual assessment of an Oral Glucose Tolerance Test. Surprisingly, glucose intolerance or overt diabetes mellitus is seldom reported in these patients. In short-term treatment ( $<2$ years), subtle changes in either fasting glycaemia or in fasting or stimulated insulinaemia with variable changes in $\mathrm{HbA1c}$ have been reported $[43,56]$. In long-term studies, only a few patients experienced transient glucose intolerance [46] or overt diabetes mellitus requiring transient insulin therapy [56]. The consequences of long-term hyperinsulinaemia in GC-treated patients are unknown and no data are available about glucose tolerance after discontinuation of rhGH treatment. Other risk factors associated with diabetes should be documented before initiating rhGH treatment, and glucose tolerance should be carefully monitored during rhGH treatment, particularly during puberty and during acute phases of the disease requiring high doses of GC.

\section{Conclusion}

The effects of rhGH treatment in GC dependent children are promising, showing that GH treatment can improve growth velocity and increase lean mass and bone mineralisation. Different variables can influence the response to rhGH therapy in these children: duration of GC treatment, height SD score at the start of the treatment, delayed or slow progression of puberty, severity of the disease and GC dose during rhGH treatment. We recommend a close collaboration between the endocrinologist and the clinician in charge of the disease, to select patients suitable for GH therapy early in the course of the disease, before the onset of severe growth delay and alterations in body composition. Long-term studies are needed to evaluate the impact of rhGH treatment on adult height and body composition. In addition, further clinical studies are needed to develop new therapeutic strategies to optimise the benefits of rhGH treatment. For example, a combined treatment using sex steroids in patients with delayed puberty or bisphosphonates to improve bone mineralisation could be tested.

Overall, the safety of rhGH treatment is good, as long as precautions are taken to minimise the risks of impaired glucose tolerance, type 2 diabetes and disease exacerbation. Careful monitoring of patients is needed to evaluate the impact of rhGH treatment on disease progression, and to modify rhGH treatment during phases of the disease that require high doses of GC. Long-term follow-up is necessary to evaluate the consequences of long-term rhGH treatment on glucose metabolism in GC-treated patients. Therefore, patients suffering from various cortico-dependent diseases and using rhGH treatment should be enrolled in clinical studies to facilitate data analysis. 


\section{References}

-1 Motil KJ, Grand RJ, Davis-Kraft L, Ferlic LL, Smith EO: Growth failure in children with inflammatory bowel disease: a prospective study. Gastroenterology 1993;105:681-691.

-2 Griffiths AM, Nguyen P, Smith C, MacMillan JH, Sherman PM: Growth and clinical course of children with Crohn's disease. Gut 1993;34:939-943.

-3 Ansell BM, Bywaters EGL: Growth in Still's disease. Ann Rheum Dis 1956;15:295-319.

4 Falcini F, Tacetti G, Trapani S, Tafi L, Volpi M: Growth retardation in juvenile chronic arthritis patients treated with steroids. Clin Exp Rheumatol 1991;9(suppl 6):37-40.

$\checkmark 5$ Simon D, Fernando C, Czernichow P, Prieur AM: Linear growth and final height in patients with systemic juvenile chronic arthritis treated with long-term glucocorticoids. J Rheumatol 2002;29:1296-300.

-6 Rees L, Greene S, Adlard P, et al: Growth and endocrine function in steroid sensitive nephrotic syndrome. Arch Dis Child 1988;63: 484-490.

7 Donatti T, Koch V, Fujimura M, et al: Growth in steroid-responsive nephrotic syndrome: a study of 85 pediatric patients. Pediatr Nephrol 2003;18:789-795.

$>8$ Emma F, Sesto A, Rizzoni G: Long-term linear growth of children with severe steroidresponsive nephrotic syndrome. Pediatr Nephrol 2003;18:783-788.

$\checkmark 9$ McEnery P, Gonzalez L, Martin L, West C: Growth and development of children with renal transplants. J Pediatr 1973;83:806814.

-10 Broyer M, Guest G, Gagnadoux M-F: Growth rate in children receiving alternate-day corticosteroid treatment after kidney transplantation. J Pediatr 1992;120:721-725.

-11 Hokken Koelega A, van Zaal M, de Ridder M, Wolff E, De Jong M, Donckerwolcke R, Muinck Keizer-Shrama S, Drop S: Growth after renal transplantation in prepubertal children: impact of various treatment modalities. Pediatr Res 1994;35:367-371.

$\checkmark 12$ Hokken Koelega A, van Zaal M, van Bergen W, de Ridder M, Stijnen T, Wolff E, De Jong M, Donckerwolcke R, de Muinck Keizer-Shrama S, Drop S: Final height and its predictive factors after renal transplantation in childhood. Pediatr Res 1994;36:323-328.

$\checkmark 13$ Fraser P, Hoch S, Erlandson D, Partridge R, Jackson J: The timing of menarche in juvenile rheumatoid arthritis. J Adolesc Health Care 1988;9:483-487.

14 van Diemen-Steenvoorde R, Donckerwolcke R: Growth and sexual maturation in paediatric patients treated by dialysis and following kidney transplantation. Acta Paediatr Scand 1988;343:109-116.
15 Schaeffer F, Veldhuis J, Stanhope R, Jones J, Schärer K, and the Cooperative Study Group on Pubertal Development in Chronic Renal Failure: Alterations in growth hormone secretion and clearance in peripubertal boys with chronic renal failure and after renal transplantation. J Clin Endocrinol Metab 1994;78:1298-1306.

16 Ballinger A, Savage M, Sanderson I: Delayed puberty associated with inflammatory bowel disease. Pediatr Res 2003;53:205-210.

17 Feber J, Dupuis JM, Chapuis F, Braillon P, Jocteur-Monrozier D, Daudet G, So S, Levrey H, Hadj-Aîssa A, Martin X, Bellon G, Cochat P: Body composition and physical performance in children after renal transplantation. Nephron 1997;75:13-19.

18 Zak M, Hassager C, Lovell DJ, Nielsen S, Henderson CJ, Pedersen FK: Assessment of bone mineral density in adults with a history of juvenile chronic arthritis. Arthritis Rheum 1999;42:790-798.

19 van Staa TP, Cooper C, Leufkens HG, Bishop $\mathrm{N}$ : Children and the risk of fractures caused by oral corticosteroids. J Bone Miner Res 2003;18:913-918.

20 Mehls O, Tönshoff B, Kovacs G, Mayer C, Schurek J, Oh J: Interaction between glucocorticoids and growth hormone. Acta Paediatr 1993; suppl 388:77-82.

21 Underwood LE: Growth retardation in chronic diseases: possible mechanisms. Acta Paediatr 1999;88(suppl 428):93-96.

-22 Klaus G, Jux C, Fernandez P, Rodriguez J, Himmele R, Mehls O: Suppression of growth plate chondrocyte proliferation by corticosteroids. Pediatr Nephrol 2000;14:612-615.

23 Jux C, Leiber K, Hügel U, Blum W, Ohlsson C, Klaus G, Melhs O: Dexamethasone impairs growth hormone stimulated growth by suppression of local insulin-like growth factor (IGF)-I production and expression of $\mathrm{GH}$ and IGF-I-receptor in cultured rat chondrocytes. Endocrinology 1998;139:3296-3305.

24 Gafni R, Weise M, Robrecht D, Meyers J, Barnes K, De-Levi S, Baron J: Catch-up growth is associated with delayed senescence of the growth plate in rabbits. Pediatr Res 2001;50:618-623.

25 Mushtaq T, Farquharson C, Seawright E, Ahmed SF: Glucocorticoid effects on chondrogenesis, differentiation and apoptosis in the murine ATDC5 chondrocyte cell line. J Endocrinol 2002;175:705-713.

26 Canalis E: Mechanisms of glucocorticoid action in bone: implications to glucocorticoidinduced osteoporosis. J Clin Endocrinol Metab 1996;81:3441-3446.

27 Beaufrère B, Horber FF, Schwenk WF, Marsh HM, Matthews D, Gerich JE, Haymond MW: Glucocorticoids increase leucine oxidation and impair leucine balance in humans. Am J Physiol 1989;257:E712-E721.
28 Rebuffé-Scrive M, Krotkiewski M, Elferson J, Björntorp P: Muscle and adipose tissue morphology and metabolism in Cushing's syndrome. J Clin Endocrinol Metab 1988;67: 1122-1128.

29 Stieger U, Lippuner K, Montandon A, Jeger P, Horber FF: Body composition and fuel metabolism after kidney grafting. Eur J Clin Invest $1995 ; 25: 809-816$.

30 Lee DY, Park SK, Kim JS: Insulin-like growth factor-I (IGF-I) and IGF-binding proteins in children with nephrotic syndrome. J Clin Endocrinol Metab 1996;81:1856-1860.

31 Savage M, Beattie RM, Camacho-Hübner C, Walker-Smith JA, Sanderson IR: Growth in Crohn's disease. Acta Paediatr 1999;88(suppl 428):89-92.

32 De Benedetti F, Alonzi T, Moretta A, Lazzaro D, Costa P, Poli V, Martini A, Ciliberto G, Fattori E: Interleukin-6 causes growth impairment in transgenic mice through a decrease in insulin-like growth factor-I. A model for stunted growth in children with chronic inflammation. J Clin Invest 1997;99: 643-650.

\33 Garibotto G, Barreca A, Russo R, Sofia A, Araghi P, Cesarone A, Malaspina M, Fiorini F, Minuto F, Tizianello A: Effects of recombinant human growth hormone on muscle protein turnover in malnourished hemodialysis patients. J Clin Invest 1997;99:97-105.

34 Hardin D, Ellis KJ, Dyson M, Rice J, McConnell R, Seilhemer D: Growth hormone decreases protein catabolism in children with cystic fibrosis. J Clin Endocrinol Metab 2001;86:4424-4428

-35 Wilmore DW: The use of growth hormone in severely ill patients. Adv Surg 1999;33:261274.

36 Horber FF, Haymond MW: Human growth hormone prevents the protein catabolic side effects of prednisone in humans. J Clin Invest $1990 ; 86: 265-272$.

$\checkmark 37$ Bennet WM, Haymond MW: Growth hormone and lean tissue catabolism during long-term glucocorticoid treatment. Clin Endocrinol 1992;36:161-164.

38 Ortoft G, Andreassen T, Oxlund H: Growth hormone increases cortical and cancellous bone mass in young growing rats with glucocorticoid-induced osteopenia. J Bone Miner Res 1999;14:710-721.

39 Tönshoff B, Haffner D, Melhs O, Dietz M, Ruder H, Blum W, Heirich U, Stöver B and the Members of the German Study Group for Growth Hormone Treatment in Children with Renal Allografts: Efficacy and safety of growth hormone treatment in short children with allografts: three years experience. Kidney Int 1993;44:199-207. 
40 Hokken Koelega A, Stijnen T, de Ridder M, de Muinck Keizer-Shrama S, Wolff E, De Jong M, Donckerwolcke R, Groothoff JW, Blum W, Drop S: Growth hormone treatment in growth-retarded adolescents after renal transplant. Lancet 1994:343:13131317.

-41 Feber J, Cochat P, Lebl J, Krasnicanova H, Stepan J, David L, Braillon P, Bonnet L, Janda $\mathrm{J}$ : Body composition in children receiving recombinant human growth hormone after renal transplantation. Kidney Int 1998;54: 951-955.

42 Mauras N, George D, Evans J, Milov D, Abrams S, Rini A, Welch S, Haymond MW: Growth hormone has anabolic effects in glucocorticosteroid-dependent children with inflammatory bowel disease: a pilot study. Metabolism 2002;51:127-135.

-43 Touati G, Prieur AM, Ruiz JC, Noel M, Czernichow P: Beneficial effects of one-year growth hormone administration to children with juvenile chronic arthritis on chronic steroid therapy. Effects on growth velocity and body composition. J Clin Endocrinol Metab 1998;83:403-409.

44 Touati G, Ruiz JC, Porquet D, Kindermans C, Prieur AM, Czernichow P: Effects on bone metabolism of one year recombinant human growth hormone administration to children with juvenile chronic arthritis undergoing chronic steroid therapy. J Rheumatol 2000;27:1287-1293.
45 Bechtold S, Ripperger P, Häfner R, Said E, Schwartz HP: Growth hormone improves height in patients with juvenile idiopathic arthritis: 4-year data of a controlled study. J Pediatr 2003;143:512-519.

46 Simon D, Lucidarme N, Ruiz JC, Prieur AM, Czernichow P: Effects on growth and body composition of growth hormone treatment in children with juvenile idiopathic arthritis requiring steroid therapy. J Rheumatol 2003; 30:2492-2499.

47 Bechtold S, Ripperger P, Bonfig W, Schmidt $H$, Bitterling $H$, Häfner R, Schwartz HP: Bone mass development and bone metabolism in juvenile idiopathic arthritis: treatment with growth hormone for 4 years. J Rheumatol 2004;31:1407-1412.

48 Bechtold S, Ripperger P, Bonfig W, Dalla Pozza R, Häfner R, Schwartz HP: Growth hormone changes bone geometry and body composition in patients with juvenile idiopathic arthritis requiring glucocorticoid treatment: a controlled study using peripheral quantitative computed tomography. J Clin Endocrinol Metab 2005;90:3168-3173.

49 Davies UM, Rooney M, Preece MA, Ansel BM, Woo P: Treatment of growth retardation in juvenile chronic arthritis with recombinant human growth hormone. J Rheumatol 1994;21:153-158.

50 Davies UM, Jones J, Reeve J, Camacho-Hubner C, Charlett A, Ansell BM, Preece M, Woo P: Effects of disease activity and recombinant human growth hormone on insulinlike growth factor 1, insulin-like growth factor binding proteins 1 and 3, and osteocalcin Arthritis Rheum 1997;40:332-340.
51 Savino W, Postel-Vinay MC, Smamiotto S, Dardenne M: The thymus gland: a target organ for growth hormone. Scand J Immunol 2002;55:442-452.

-52 Slonim A, Bulone L, Damore M, Goldberg T, Wingertzahn M, Mc Kinley M: A preliminary study of growth hormone therapy for Crohn's disease. N Engl J Med 2000;342: 1633-1637.

53 Fine, R, Stablein D, Cohen A, Tejani A, Kohaut E: Recombinant human growth hormone post-renal transplantation in children: a randomized controlled study of the NAPRTCS. Kidney Int 2002;62:688-696.

54 Guest G, Bérard E, Crosnier H, Chevallier T, Rappaport R, Broyer M: Effects of growth hormone in short children after renal transplantation. Pediatr Nephrol 1998;12:437446.

55 Horber FF, Marsh M, Haymond MW: Differential effects of prednisone and growth hormone on fuel metabolism and insulin antagonism in humans. Diabetes 1991;40:141149.

56 Allen D, Julius J, Breen T, Attie K: Treatment of glucocorticoid-induced growth suppression with growth hormone. J Clin Endocrinol Metab 1998;83:2824-2829.

57 Van Es A: Growth hormone treatment in short children with chronic renal failure and after renal transplantation: Combined data from European clinical trials. The European Study Group. Acta Paediatr Scand Suppl 1991;379:42-48. 